\title{
Relationship between Selected Physiographic Features and Landslide Occurrence around Four Hydropower Projects in Bhagirathi Valley of Uttarakhand, Western Himalaya, India
}

\author{
Hari Ballabh ${ }^{*}$, Srinivasan Pillay ${ }^{1}$, Girish Chandra Singh Negi², Kamleshan Pillay ${ }^{1}$ \\ ${ }^{1}$ School of Agricultural, Earth \& Environmental Sciences, College of Science and Agriculture, University of \\ KwaZulu-Natal, Westville Campus, Durban, South Africa \\ ${ }^{2}$ G. B. Pant Institute of Himalayan Environment and Development, Kosi-Katarmal, Almora \\ India \\ Email: " ballabh2228@gmail.com, Pillays2@ukzn.ac.za, negigcs@gmail.com, pillay.kamleshan@gmail.com
}

Received 15 May 2014; revised 12 June 2014; accepted 5 July 2014

Copyright @ 2014 by authors and Scientific Research Publishing Inc.

This work is licensed under the Creative Commons Attribution International License (CC BY).

http://creativecommons.org/licenses/by/4.0/

(c) (i) Open Access

\section{Abstract}

The Himalayan mountain range is an internationally recognised landscape but one under increasing developmental threat. The lower Himalayan region possesses immense potential for hydropower generation but is also highly susceptible to tectonic deformation and mass wasting, especially landslides. Susceptibility to landslides increases markedly with human activity, especially large scale developmental projects. The impacts of massive hydropower plant construction in the Bhagirathi Valley, Uttarkhand, India on the generation of landslides are the focus of this study. Whilst many positive impacts derive from such projects, devastating negative impacts also accrue. The frequency and characteristics of land sliding within the sphere of influence of the construction sites of the various hydropower plant components were investigated. Landslide frequency was related to parameters of geology, prior land use, drainage density, slope steepness and location in terms of construction aspect. Landslide frequency was found to be greatest in gneissic terrain as well as on previously agricultural and forested lands. Statistical analysis revealed significant relationships between landslide frequency with slope and, frequency with construction aspect, especially the construction of access roads. As with other studies, road construction is the key initiator of land sliding due to slope over steepening and the indiscriminate dumping of debris. The study concludes with recommendations for reducing the frequency and magnitude of mass wasting in

${ }^{*}$ Corresponding author.

How to cite this paper: Ballabh, H., Pillay, S., Negi, G.C.S. and Pillay, K. (2014) Relationship between Selected Physiographic Features and Landslide Occurrence around Four Hydropower Projects in Bhagirathi Valley of Uttarakhand, Western Himalaya, India. International Journal of Geosciences, 5, 1088-1099. http://dx.doi.org/10.4236/ijg.2014.510093 


\section{this environment.}

\section{Keywords}

Landslide, Himalayas, Bhagirathi Valley, Development, Hydropower Plants

\section{Introduction}

The geodynamically active Himalayan mountain range [1] is highly susceptible to mass wasting phenomena, particularly landslide [2] [3] which are generally recognised as important agents of mass wasting and hill slope evolution in mountainous regions [4]. Causes of landslides in this region are attributable to natural drivers such as the great relief, steep slopes, poor or youthful soil development, active tectonism, freeze-thaw processes at high altitudes and accelerated soil saturation and erosion due to high intensity monsoonal rains. Anthropogenic impacts concomitant with increased occupation of steeper terrain serves only to increase the landslide hazard in the Himalayas [5] [6], where such incursions of sensitive terrain are coupled with large developmental projects, the threat of mass wasting is increased multifold.

In the case of the Himalayan region, the high degree of human interference in the sphere of influence of project sites such as major hydropower project construction triggers frequent disturbances, especially mass wasting phenomena such as landslides, due to the fragile natural environment and the delicacy of the ecology [7] [8].

In such cases, assessment of the positive and negative impacts, mitigation measures and, a sound understanding of the natural rehabilitative potential of the land to be able to adjust to new equilibria following the disruptions should precede the actual development.

Recent years have seen a renewed push for building dams in the Himalayas. Massive plans are underway in Pakistan, India, Nepal and Bhutan [9] to build several hundred dams in the region, with over 150,000 Megawatts (MW) of additional capacity proposed in the next 20 years in the four countries. If all the planned capacity expansion materialises, the Himalayan region would have the highest concentration of dams in the world.

Developmental activities such as hydroelectric power projects (HEPs) bring many positive and negative impacts during different phases of construction and development.

During the construction period especially, negative impacts outweigh the positive impacts. While expressing concern over adverse environmental impacts of HEPs, one should also visualize the benefits brought about by these projects to the region and its residents. Hydropower is a renewable source of energy which is economic to produce, pollution free and could be more compatible with environmental conservation imperatives [10]. It has provided many direct benefits in terms of hydroelectricity, irrigated agriculture, water supply, flood control and drought protection. For instance, Kuniyal and Sharma [8] observed in the Kullu Valley, Himachal Pradesh, that employment, economic benefit and infrastructure development were the main positive impacts due to construction of Parbati II (800 MW), Parbati III (520 MW) and Malana (86 MW) hydropower projects in the upper Beas Valley.

However, during different construction and operational phases, the HEPs may represent some of the worst adverse impacts in the form of inundation of adjacent forest lands, submergence of riparian vegetation and heritage sites of the local residents and, excessive soil loss through erosion and landslides in the construction of roads and other project appurtenances. During the construction phases of HEPs, detrimental impacts on fresh water ecosystems, fisheries and flood dependent agriculture are often declared to be unavoidable.

Despite the huge public outcry from environmentalists and generally, people of the Hindu faith in India and elsewhere against any project involving the sacred Ganges River or the Himalayas, development of HEPs has nevertheless increased substantially in recent years.

The Upper Bhagirathi Valley of the Ganga River has witnessed, over the past decade, the development of a series of hydro-electric power projects, causing severe disruption of the natural environment. Damage to the environment has been widely reported in the media, whilst government agencies and developers have argued to the contrary. Here we present an assessment of the impact of HEP development in the Bhagirathi valley on the frequency, distribution and characteristics of landslides. Further, some recommendations based on mitigation and remediation of landslides are suggested. 


\section{Physiographic Description of the Study Area}

The Bhagirathi River basin, the focus of this study lies within the district of Uttarkashi, in the state of Uttarkhand, northern India, between $30^{\circ} 36^{\prime} \mathrm{N}, 78^{\circ} 11^{\prime} \mathrm{E}$ (Dharasu) and $31^{\circ} 00^{\prime} \mathrm{N}, 78^{\circ} 54^{\prime} \mathrm{E}$ (Gangotri) (Figure 1). This is a region of high relief ranging from $830 \mathrm{~m}$ to $3010 \mathrm{~m}$ and mountainous topography.

Snow, ice and glacier fields in upper Bhagirathi basin form natural reservoirs contributing to the perennial water resource feeding the river system which eventually forms the primary water resource at Uttarkashi and further downstream. Within the $129 \mathrm{~km}$ long Bhagirathi valley flows the Bhagirathi River together with its numerous tributaries.

The climate of the area varies from the dominant sub-tropical monsoon type [11] in the lower reaches to upland tropical and finally to sub-arctic in the highest reaches of the Bhagirathi valley which is under perennial snow cover. The region is characterised by four distinct seasons: cold winter (December to February), hot summer (March to May), the southwest monsoon (June to September) and the post-monsoon season (October to November).

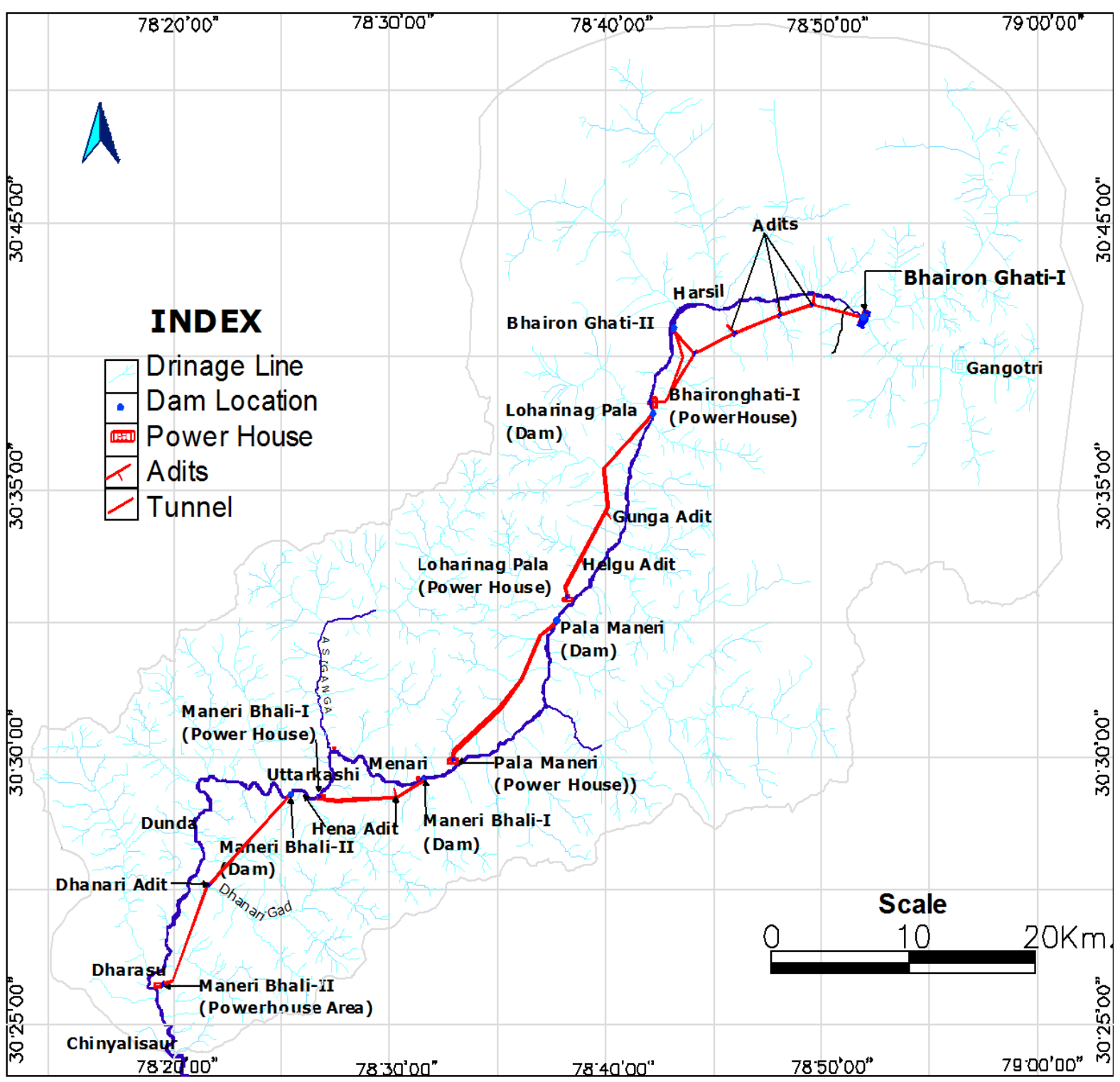

Figure 1. Location of the study area extending from Dharasu to Gangotri with relevant construction aspects in Bhagirathi valley. 
Maximum rainfall occurs during the monsoon season when $75 \%$ of the rainfall is recorded. Rainfall then decreases sharply to a minimum in November. Approximately $17 \%$ of the balance of precipitation occurs as snowfall in the higher elevations of the catchment and associated with the passage of western disturbances. Preand post-monsoonal thunderstorms account for much of the remainder of the annual precipitation. In accord with the changing climate regime with altitude, mean annual rainfall increases up catchment from $1095.0 \mathrm{~mm}$ at Dharasu to $1917.5 \mathrm{~mm}$ at Jamuna Chetty to $2092.9 \mathrm{~mm}$ at Kharsali [12]. Numerous microclimates exist within the Bhagirathi Valley controlled by valley aspect, proximity to glaciers and altitude [13].

The geology of the region, as with much of the Himalayas, is complex, following repeated tectonism. Rocks of the Garhwal Lesser Himalaya and Higher Himalaya sequences are separated by the main central thrust (MCT) which passes approximately mid-way through the area. Establishing stratigraphic sequences in the Garhwal Himalaya is difficult since rocks of the area have suffered high levels of deformation due to repeated folding, faulting and thrusting [14].

Broadly, four major lithological units, the Sub-Himalayan Shiwaliksediments, the Lesser Himalayan Metasedimentary sequences, the Higher Himalayan crystallines and the Tethyan Sedimentary successions [15] are found north-east to south-west across the Bhagirathi Valley. The main rock types are quartzites, phyllites, slates, gneisses, intrusive granites and metabasics. Deformation of rocks in the valley has induced secondary porosity vital for the groundwater occurrence and movement.

The rocks of the region are characterized by multiple structural discontinuities and the relationship of these with slope often makes conditions favourable for landslides to occur [12]. Korup [24] similarly observed that in tectonically active mountain belts such as the collisional orogen of the Southern Alps, New Zealand, frequent land sliding and fluvial dissection are the main agents of denudation. In such tectonically sensitive regions, alteration of the landscape due to human activities plays an important role in triggering landslides.

The threat of landslides is further heightened if the soil character is considered. Soils of the Bhagirathi Valley are generally poorly developed due to the steep topography and highly erosive rainfall regime. Soils on slopes are shallow, excessively drained with weak horizon development and with lithic contact within $50 \mathrm{~cm}$ of the surface. Broader valleys with gentler slopes show better soil development but the generally low organic matter content and high stone content due to slow chemical weathering gives the soils a highly erodible character particularly during high intensity rainfalls.

The assigned study area, embracing the entire Bhagirathi valley, includes a number of towns en route, beginning with Dharasu, followed sequentially upstream by Dunda, Gyansu, Uttarkaski, Gangori, Netala, Maneri, Bhatwari, Gangnani, Zhala, Harsil and Lanka (Figure 1).

Human habitations vary in size from isolated hamlets to dense settlements mostly situated along roads. These are located on hill slopes at significantly higher elevation compared to the Bhagirathi River. The main sources of water supply for the people, animals and for agriculture are hill streams (locally known as Gad, Gadheras or Khads) and springs. The Bhagirathi River possess a huge amount of naturally beautiful and lofty mountain scenery, undisturbed for millennia, but under threat of development in recent times.

The HEP projects include the Bhaironghati I (BG-I, 240 MW and under consideration), Loharinag Pala (LNP, $600 \mathrm{MW}$ and approximately 60\% complete), Pala Maneri (PM, $480 \mathrm{MW}$ at project initiation stage: two roads constructed), the fully established and operational ManeriBhali I (MB-I, 90 MW) and, ManeriBhali II (MB-II, $304 \mathrm{MW}$ ) (Figure 2). Thereafter follows the Tehri Dam reservoir which has a river length of up to $35 \mathrm{~km}$.

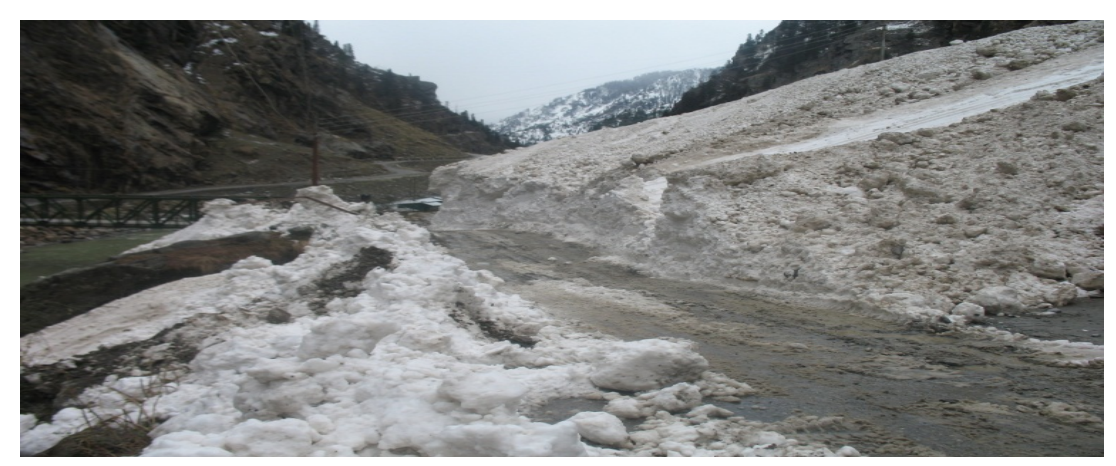

Figure 2. Avalanche at Dabrani Adit across the National Highway 108 (NH-108). 


\section{Methodology}

A comprehensive field survey of landslides associated with the different phases of each of the HEP developments in the Bhagirathi valley was undertaken. All physiographic data at each site was recorded together with manual measurements of the dimensions of each of the landslides. Prior land use of the sites was also recorded together with secondary information of the relative slope stability of the area. In addition, data on muck (construction debris) disposal which, in itself, constitute a potential landslide hazards, was also recorded. The database was supplemented by secondary data such as EIA (Environmental Impact Assessment) report and DPR (Detail Project Report) of the projects on the local geology for each developmental site together with information on muck disposal requirements. Slope analysis was done with the help of topographical sheets of survey of India and Google Earth imagery.

All data was compiled and collated for statistical analysis. Here we have used Chi Square and Logistic Regression to ascertain the parameters most likely to have induced the land sliding to have taken place. This is important as it highlights the main landslide causative factors and forms the basis for introducing better stability measures to reduce the susceptibility risk.

Statistical analysis was undertaken in SPSS version 21 for Windows and Prism Graphpad. Several Analysis of Variance (ANOVA) tests were performed to determine whether there was a significant difference between landslide frequency and slope, drainage, land use, geology and location of particular HEP development aspects. If combinations were found to be statistically significant, the Tukey multi-comparison test was used to determine between which combinations differences exist. To further investigate these combinations of variables, a logistic regression model was performed. This was used to determine whether a cause and effect relationship was present between variables. Logistic regressions are often used within landslide studies as they are able to analyse qualitative and quantitative variables simultaneously. For the purposes of this logistic regression model, the variables were separated into classes according to Table 1. All assumption tests for normality and homoscedasticity were accepted if $p>0.05$, else they were transformed using a log transformation. The assumption tests for linearity were assessed visually by using scatterplots for quantitative variables.

\section{Results and Discussion}

The impact of HEP development in the Bhagirathi Valley has resulted in a number of landslides that have seriously affected the environment. Table 2 presents composite information relating to each HEP development component, the road construction characteristics and debris produced, the number and magnitudes of mass wasting phenomena produced, the physiographic characteristics and the prevailing land use of the area prior to development.

In terms of the geology of the zones of the greatest incidence of mass wasting, these have occurred in previously relatively stable lithologies of igneous and metamorphic terrain. This may seem unusual because although prior tectonism and deformation would have induced some reduction of internal strength of these rock types, their inherent physical solidity and complex chemical composition generally make them susceptible to chemical decomposition rather than the more dominant mechanical weathering processes of the Himalayan highlands.

At the LNP HEP power house, the $1.31 \mathrm{~km}$ road leading to the HelguAdit is an extension of the National Highway (NH-108) and is cut into terrain comprising gneisses and schistose rocks but recorded six landslides with a total affected area of approximately $0.32 \mathrm{~km}^{2}$.

Table 1. Variables separated into qualitative classes for the logistic regression model.

\begin{tabular}{cc}
\hline Variable & Classes \\
\hline $\begin{array}{c}\text { Landslide frequency } \\
\text { Slope }\end{array}$ & $<2,>2$ \\
Drainage & Low, Medium, High \\
Land use & River bed, Agriculture, Grassland, Forest, Old debris \\
Geology & Gneisses, Mixed Basic, Metabasics, Gravel Deposits, Quartzite, Phyllites, Mica Schists \\
Location (HEP aspect) & Dam Site, Adit, Other
\end{tabular}


Table 2. Composite physiographic and landslide data at various construction components of HEP projects in the Bhagirathi Valley.

\begin{tabular}{|c|c|c|c|c|c|c|c|c|}
\hline HEP & Component & $\begin{array}{l}\text { No. of } \\
\text { land-slide }\end{array}$ & Road construction & $\begin{array}{l}\text { Road } \\
\text { length }(\mathrm{m})\end{array}$ & Debris & Geology* & Land use & $\begin{array}{l}\text { Slope in } \\
\text { Degree }\end{array}$ \\
\hline \multirow{9}{*}{ 1.LNP } & Dam Site & 2 & Widening of $\mathrm{NH}$ & 1275 & 2 & $\begin{array}{l}\text { Quartz-mica feldspathic } \\
\text { gneisses with quartz veins }\end{array}$ & Degraded Forest & 47.98 \\
\hline & Fore Way & 0 & NH to Muck site & 200 & 10 & $\begin{array}{l}\text { Quartz feldsphatic gneisses, } \\
\text { over burden consisting of } \\
\text { gneisses boulders in a silty } \\
\text { sandy matrix with two } \\
\text { sand horizon }\end{array}$ & Old rock fall & 29.25 \\
\hline & DabraniAdit & 5 & NH to adit & 650 & 5 & $\begin{array}{l}\text { Quartz-mica feldspathic } \\
\text { gneisses with quartz veins }\end{array}$ & $\begin{array}{l}\text { Grass land with } \\
\text { thin forest }\end{array}$ & 23.75 \\
\hline & GungaAdit & 7 & NH to Gungaadit & 3888 & 5 & $\begin{array}{c}\text { Mica schist with meta basics } \\
\text { and gneissic band having } \\
\text { quartz veins }\end{array}$ & Dense forest & 36.13 \\
\hline & HelguAdit & 6 & NH to Helguadit & 1310 & 3 & $\begin{array}{l}\text { Biotite gneisses and augen } \\
\text { gneisses with schist and } \\
\text { meta basic bend }\end{array}$ & Grass land & 33.82 \\
\hline & Surge Shaft & 3 & $\begin{array}{c}\text { NH way to Kunjan } \\
\text { village }\end{array}$ & 4285 & 3 & $\begin{array}{l}\text { Migmatites, mica gneisses, } \\
\text { schist and meta basic band }\end{array}$ & $\begin{array}{l}\text { Grass agriculture } \\
\text { land }\end{array}$ & 33.42 \\
\hline & Pressure Shaft & 4 & $\begin{array}{l}\text { Kunjan Road } \\
\text { Pressure Shaft }\end{array}$ & - & 2 & $\begin{array}{l}\text { Migmatites, mica schist } \\
\text { Augen gneisses, quartz-mica } \\
\text { gneisses with schist }\end{array}$ & Agriculture land & 31.80 \\
\hline & Power House & 5 & Widening of $\mathrm{NH}$ & 2750 & 5 & $\begin{array}{l}\text { Migmatites quartz-mica } \\
\text { gneisses with schist band }\end{array}$ & $\begin{array}{l}\text { Agriculture/grass } \\
\text { land }\end{array}$ & 47.98 \\
\hline & $\begin{array}{l}\text { Tail Race } \\
\text { Tunnel }\end{array}$ & 1 & - & - & 2 & $\begin{array}{l}\text { Migmatites Mica schists, } \\
\text { Augen gneisses Quartz } \\
\text { mica gneisses with schist }\end{array}$ & $\begin{array}{l}\text { Grass with thin } \\
\text { forest }\end{array}$ & 30.96 \\
\hline \multirow{2}{*}{ 2.PM } & Dam Site & 1 & $\begin{array}{l}\text { Widening of NH Swari } \\
\text { Gad to Thirang }\end{array}$ & 2500 & 1 & $\begin{array}{l}\text { Foliated and joined fresh } \\
\text { gneisses and schist }\end{array}$ & Thick forest & 27.47 \\
\hline & Power House & 1 & $\mathrm{NH}$ to Aungi village & 1100 & 1 & $\begin{array}{l}\text { Foliated Fresh quartzite } \\
\text { schists and meta basics }\end{array}$ & Agriculture land & 35.37 \\
\hline \multirow{2}{*}{ 3.MBI } & Dam Site & 1 & $\begin{array}{c}\text { Dam axis to Jamak } \\
\text { village }\end{array}$ & 400 & 1 & Quartzite with clay & Agriculture land & 17.74 \\
\hline & Power House & - & $\begin{array}{l}\text { Tiloth bridge to } \\
\text { powerhouse }\end{array}$ & 200 & 1 & $\begin{array}{l}\text { Gravel deposit with } \\
\text { schist with schist }\end{array}$ & $\begin{array}{l}\text { Agriculture } \\
\text { settlement }\end{array}$ & 23.75 \\
\hline \multirow{5}{*}{ 4.MBII } & Dam Site & - & $\begin{array}{l}\text { Joshiyara bridge to } \\
\text { MB IIdam axis }\end{array}$ & 500 & - & $\begin{array}{l}\text { Quartz with slate band } \\
\text { and meta basic rocks }\end{array}$ & $\begin{array}{l}\text { Agriculture } \\
\text { settlement }\end{array}$ & 6.28 \\
\hline & DhanariAdit & - & $\begin{array}{l}\text { Dhanari road } \\
\text { to adit }\end{array}$ & 7000 & 1 & Meta Basics and Slate & Agriculture land & 16.20 \\
\hline & Surge Shaft & 1 & $\begin{array}{l}\text { NH } 108 \text { to Dharasu } \\
\text { Power house and } \\
\text { surge shaft }\end{array}$ & 1000 & 1 & $\begin{array}{l}\text { Basic, meta basic, } \\
\text { ultra basic rocks }\end{array}$ & Forest land & 23.75 \\
\hline & Pressure Shaft & - & - & & 1 & $\begin{array}{l}\text { Quartzite with green } \\
\text { greyish gneisses }\end{array}$ & Forest land & 27.47 \\
\hline & Power House & 3 & $\begin{array}{l}\text { NH } 108 \text { to Dharasu } \\
\text { Power house }\end{array}$ & 5420 & 3 & $\begin{array}{l}\text { Phyllites and greywackes } \\
\text { are the main rock }\end{array}$ & Agriculture land & 18.26 \\
\hline
\end{tabular}


A contributing factor would be the steep slope $\left(33.82^{\circ}\right.$, Table 2$)$ on which the road and adit is constructed. Previously, however, this area was stable, incurring no human influence, with lower level grassland and mixed pine forests higher up.

The $4.5 \mathrm{~km}$ road that connects the powerhouse, surge shaft and pressure shaft at LNP to Tihar Village was widened during the course of development over a $2.75 \mathrm{~km}$ stretch in mixed migmatite quartz-gneiss-schist geology and recorded 11 landslides. This is a very steep environment (47.98 slope-Table 2$)$ with some agriculture and natural grassland.

Seven slides were recorded for the $3.89 \mathrm{~km}$ Ganganani road to the Gungaadit of the LNP HEP. This road is also situated on formerly stable geology of schists with meta-basics in a previously densely forested landscape with some agriculture practised in the upper reaches. The land slope here $\left(36.13^{\circ}\right)$ is steeper that that at the Helguadit and this may account for the greater severity of mass wasting at this site.

The gneissic terrain of the Dabraniadit at Loharinag Pala yielded five episodes of sliding despite the relatively gentle slopes $\left(23.75^{\circ}\right)$ and the fact that the road is only $0.65 \mathrm{~km}$ long. In this area, avalanches are common (Figure 2) hence any disruption of the natural landscape is likely to enhance the susceptibility of mass wasting. Here, even well-established grassland in relict avalanche terrain with the upper highlands are covered with scattered Devdar forest are also noted to be vulnerable to landslides.

At the construction site of the barrage of the Pala Maneri dam (Table 2), a road leading to the National Highway (NH-108) was constructed. This new road construction also generated considerable debris on the downslope side and along the Bhagirathi River. At the power house site of Pala Maneri HEP, a landslide occurred above the NH-108 (due to heavy blasting).

In the case of Maneri Bhali I, arelict landslide developed on a steep slope and relatively loose base material is located adjoining the village Jamak. At Maneri Bhali II, six landslides were recorded within the project area. The Dhanariadit area, on the other hand, is severely affected by excavation activity and disposal of cemented debris over a total area of $7.08 \times 10^{5} \mathrm{~m}^{2}$ (Figure 3).

From the analysis of variance tests, the only statistically significant differences between any of the combinations of variables were between landslide frequency versus slope ( $p<0.05,90 \%$ confidence) and landslide frequency versus their locations ( $p<0.05,95 \%$ confidence).

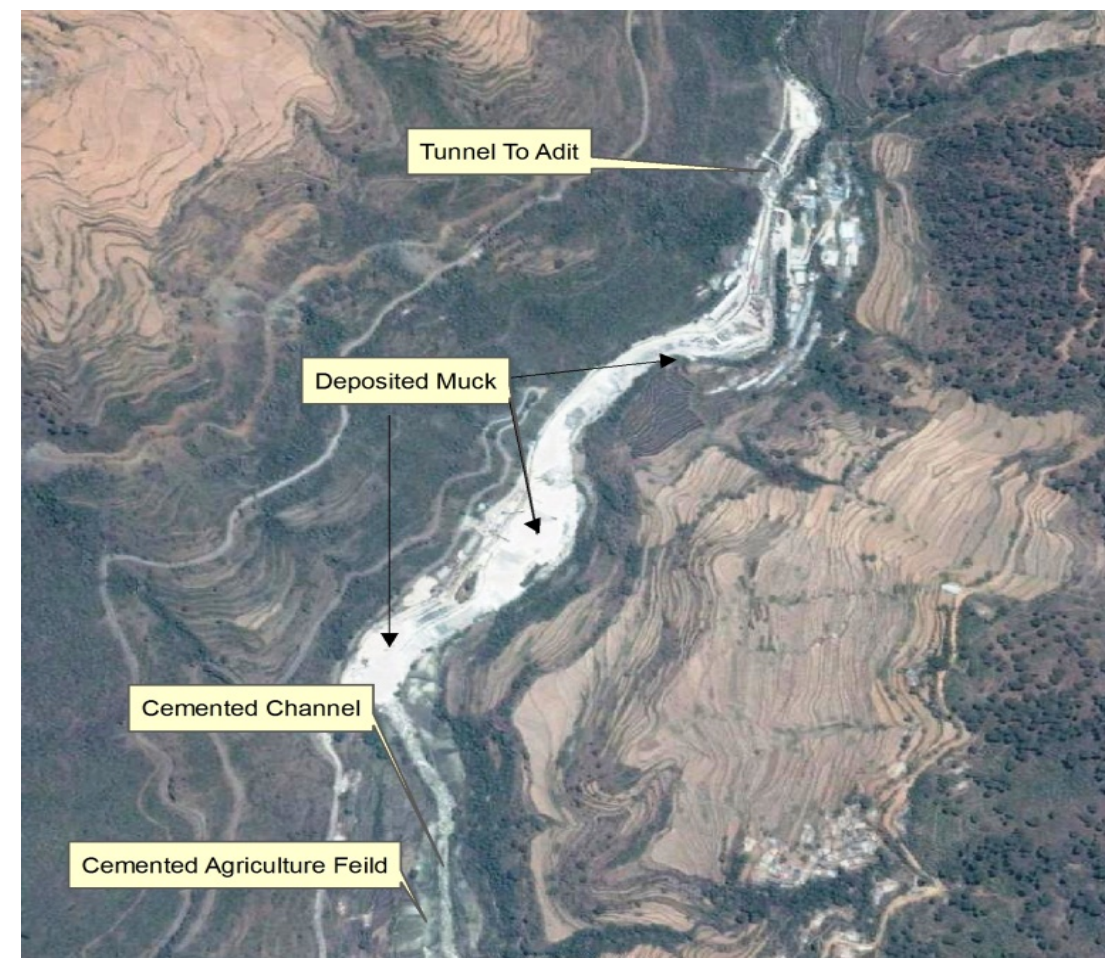

Figure 3. Google Earth ${ }^{\circledR}$ image showing the deposited debris and waste cement along the Dhanari Gad at DhanariAdit. 
Linear regression results confirm the statistically significant trend between slope and landslide frequency ( $p=$ $0.024<0.05, \mathrm{~N}=18$ ). The positive relationship is weak and this is denoted by an explained variation ( $\mathrm{R}$ Square) of only $27.84 \%$ (Figure $4(\mathrm{f})$ ). The low R2 for the relationship between frequency and slope is unusal and is here ascribed the insufficient data on this aspect.

The multi-comparisons test between the landslide frequency and slopes could not be performed as there was only one case of slopes $<10^{\circ}$ sampled. The multi-comparison test for the combination landslide frequency versus locations indicates that a significant difference exists between dam sites and adit sites $(p<0.05)$. Clearly, construction of adits presents the likelihood of increased incidence of land sliding because of the need for construction of access roads that are generally located at higher elevation than river beds.

In terms of the aim of this study, these results support the contention that human intervention in the natural environment is a key driver of landform instability, inducing and increasing the frequency of mass wasting phenomena, particularly landsliding because of the need for the construction of roads leading to adit that are previously located at higher elevations.

Figure 4(a) shows that the largest number of landslides was recorded at sites of HEP adits and at other HEP developmental aspects such as powerhouses, surge shafts, etc. (Table 2). This high concentration of landslides

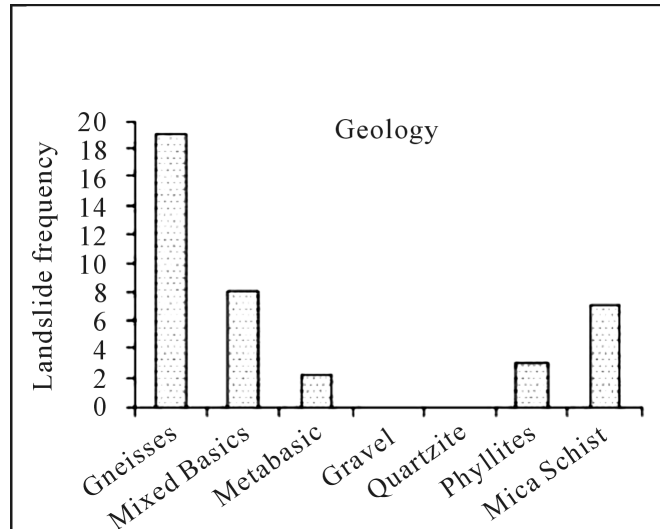

(a)

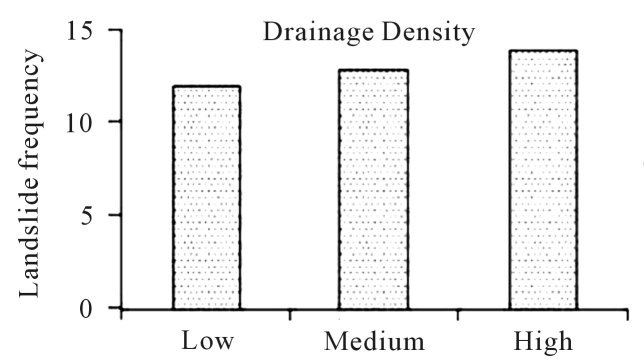

(c)

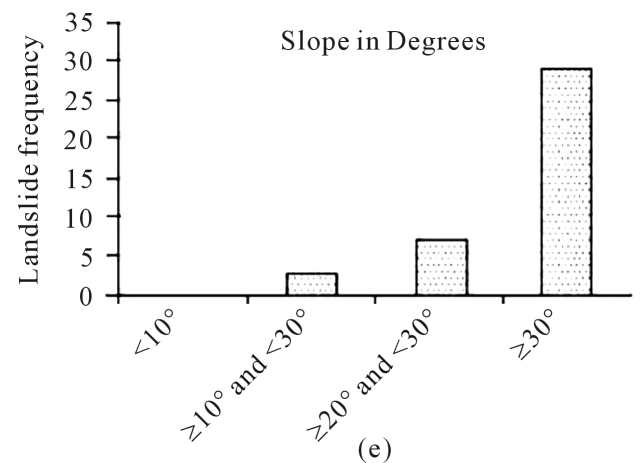

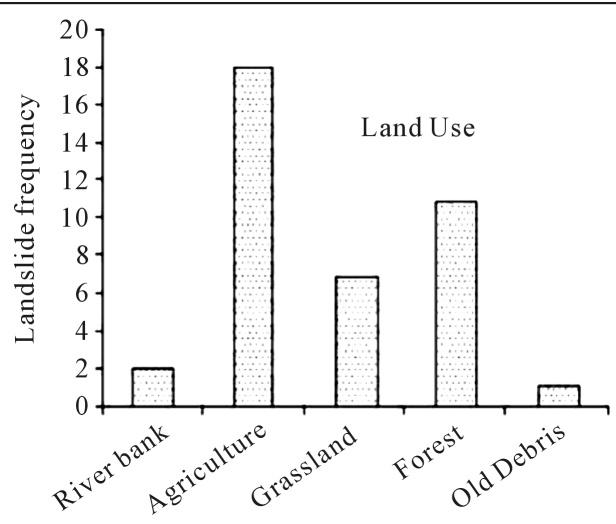

(b)

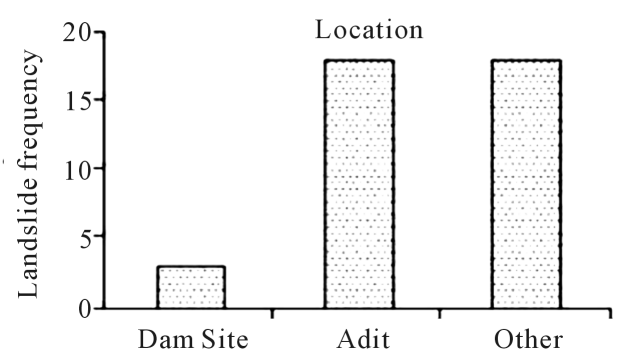

(d)

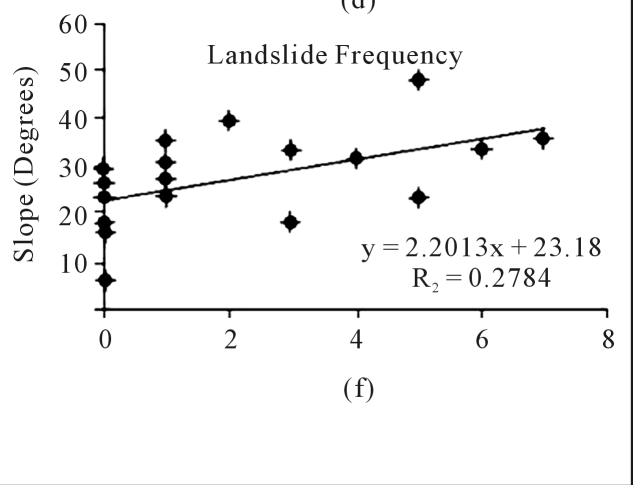

Figure 4. (a)-(e) Landslide frequency in relation to geology, drainage, slope, location of HEP development type and land use; (f) Regression of landslide frequency and slope angle. 
at developmental sites can be related to the other factors presented in Table 2. In terms of landslide frequency related to prior land uses of HEP sites (Figure 4(b)), agricultural lands and natural forests were most susceptible to mass wasting, followed by natural grassland areas. It is well recognized that natural vegetation provides a protective ground cover and their removal sharply increases the susceptibility of mass wasting. Likewise, cultivated slopes are prone to mass wasting following the steepening of slopes which is a common occurrence at road cuttings. The higher landslide frequency experienced in agricultural areas is reflective of the decreased stability inherent in disturbed landscapes in these mountainous regions. Slope stabilities is easily compromised in the Himalayan region which cause disturbances. Agricultural actuate therefore yield higher incidence of landslides.

The various types of gneisses (Table 2) form much of the geological setting of HEP sites in the Bhagirathi Valley and have recorded the highest incidences of land sliding (Figure 4(a)). Rocks of mixed basic constitution and mica schists are the next most susceptible lithology whilst quartzites are generally very stable terrain. In terms of this study, it is important to note that the HEP development in the study area is mainly located in the Higher Himalaya crystallines and the Lesser Himalaya meta-sedimentary sequences, which are seismically highly sensitive. This is further corroborated by the contention of several authors [16]-[19] that the region north of the Main Central Thrust is seismically active, experiencing rapid uplift. Additionally, Valdiya [20] point out that the NE-SE trending terrain boundary thrusts of these lithological units are tectonically active. Surprisingly, the gravel and mica schist terrain did not record any landslide possibly due to the fairly low slope angle $\left(23.75^{\circ}\right)$ and the minimal debris deposit.

The drainage density of the HEP locations showed minimal influence on landslide frequency (Figure 4(c)) but slope angle was directly related to HEP development showing a concordant increase with increasing slope angle (Figure 4(e)). Very steep slopes $\left(>30^{\circ}\right)$ recorded the highest incidence of landslides and highlight their susceptibility to any form of activity. This confirms what many researchers have shown [21] that the slope factor forms one of the principal parameters governing mass wasting activity.

For the logistic regression model, it was determined that the classification accuracy of the intercept (null model) was only $55.6 \%$ indicating a poor predictive capacity of the model. The null model tests the likelihood of landslide frequency being $\leq 2$ as opposed $>2$. From the analysis, we can accept the null hypothesis that there is indeed an equal chance of observations being one of these two classes as indicated by a Wald statistic of 0.221 . According to the Chi-square tests, there is little or no predictive capacity when variables are included into the logistic model $\left(\mathrm{X}_{2}=5.530, p=0.355>0.05\right)$. Furthermore, pseudo $\mathrm{R}$ square values indicate that this logistic regression model was not feasible (Cox and Snell R Square $=0.264$, Nagelkerke R Square $=0.354$ ). Details of insignificant $p$ values of independent variables are indicated in Table 3.

\section{Conclusions}

This study investigated the impacts of the massive HEP development projects in the Bhagirathi Valley on the generation of landslides. The principal cause of landslides has been the construction of access roads that snake upslope to particular development sites. At the very inception of these projects, access roads have to be constructed in a short timeframe to allow for heavy equipment and construction materials to be brought to site. Rapid road construction invariably involves the use of explosives to blast a pathway through resistant rock strata along the mountain slopes. This causes fracturing, shattering and jointing of the surrounding rock strata, particularly on the upslope side of roads. These fractures allow for the rapid seepage and preferential movement of

Table 3. Logistic regression for predicting landslide frequency.

\begin{tabular}{ccccc}
\hline Predictor & $\mathrm{B}$ & Wald $X^{2}$ & $p$ & Odds Ratio \\
\hline Slope & -0.103 & 1.590 & 0.207 & 0.902 \\
Drainage & -0.600 & 0.470 & 0.493 & 0.549 \\
Land Use & -0.777 & 1.140 & 0.286 & 0.460 \\
Geology & 0.143 & 0.180 & 0.671 & 1.154 \\
Location & 0.828 & 0.838 & 0.360 & 2.290 \\
\hline
\end{tabular}


water. Further, freeze-thaw processes lead to greater dislocation of fragments and decrease the slope stability further. Debris from the process is discarded on the downslope side. This material is unconsolidated, highly unstable and has contributed to a large number of the landslides recorded in the course of this study. Similar conclusions about landslide causes being attributed to road construction in this region were made by Bernard [22] who estimated that approximately, two-thirds of the landslides in the Garhwal Himalaya region were initiated or accelerated by human activity, mostly by the removal of slope toes at road cuts. Also, Owen [23] attributed road construction as one of the six causative factors of the numerous landslides experienced during the 2005 Kashmir earthquake. Heavy monsoonal rains or cloudbursts may easily trigger rapid mass movement of the unstable upslope material that crashes down onto and across the road. This rapidly travelling material then sets off movement of the downslope debris, thus escalating the phenomenon. Such slides and rock falls have occurred at the sites of the power house, surge shaft, pressure shaft, Gungaadit (Figure 5) and Dabraniadit area of LNP.

In order to minimize the percolation of water into the slide zone of all landslides as well as areas highly susceptible to mass wasting, lined drains are recommended in the upslope portions of the landslip together with the insertion of stability rods pinning sections of the regolith onto the solid underlying rock. Indiscriminate dumping of debris and cement, particularly onto the riparian zones and river channel itself must be totally discontinued. The installation of gabion baskets (wire crates) anchored with stability rods is recommended for the toe of landslides prone to further movement. These baskets are also recommended for retaining the vast amounts of debris dumped in parts of the riparian zones of the Bhagirathi River. This would help in retaining the critical mass for some time whilst stabilizing vegetation growth occurs.

\section{Suggestions}

It is well documented that the Himalayan region is one of high environmental sensitivity due to the extremely steep slopes; thrusted, folded, faulted and often friable lithologies; high drainage densities; excessive erosion of poorly developed soils and a range of active weathering processes in varied weather conditions. Minimizing the adverse impacts of any development in this fragile mountain region requires due environmental consideration. Large scale HEP developments certainly would require more sophistication in technology and techniques. The following suggestions are designed to introduce a new pattern of excavation, which could boost trust, and aid restoration of impacted parts of the environment.

Prefeasibility reports, Environmental Impact Assessments and Environmental Management Plans that contain stringent measures for all aspects of the development, especially the construction of roads and adits should be strictly adhered to, including the careful adherence to the preservation of valuable biota such as the mountain forests. Developers need to exercise particular control of heavy blasting. The friable nature of many of the

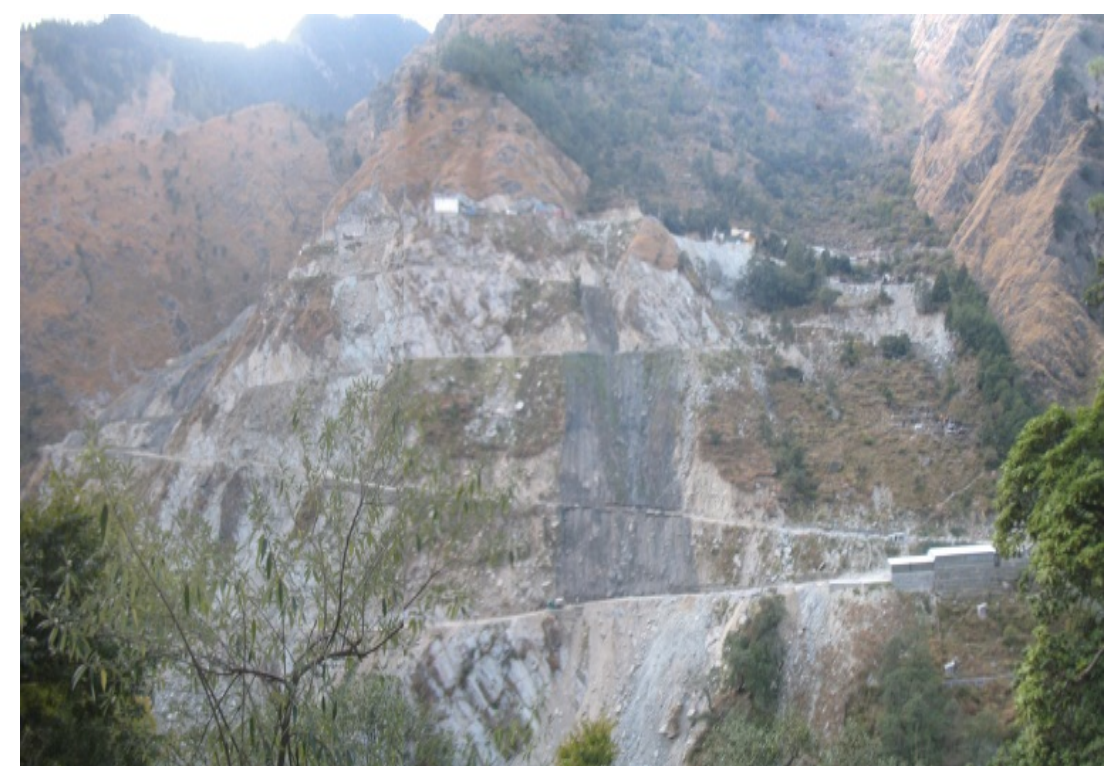

Figure 5. Debris deposits and mass wasting along the road access to the Gungaadit. 
lithologies, particular those that have endured tectonic deformation, is prone to mass wasting even with minimal disturbance. Heavy blasting should be accompanied with techniques for muffling blast impacts that concentrate blast impacts in the target zone primarily and effectively dampen effects away from this zone. This is also critically important where blasting takes place in close proximity to settlements. Iindiscriminate disposal of debris have been observed at various locations, contrary to the management plans stipulations. These deposits are highly susceptible to mass wasting. Developers have to be made more accountable and should make every effort to stabilize such deposits.

Roads should be properly metalized or the facilities for dust quenching need to be created. Construction of check-walls on either of the side of roads as well as along adjacent stretches of rivers and nallahs is essential as these margins are prone to landslips and landslides

Slope stabilization in this fragile environment with frequent occurrence of mass wasting need to be managed with micro-level bioengineering techniques in the upslope regions. Shrubs, trees and grassing of affected slopes where the erosion potential is high is essential Bio-structures of vegetation like brush layering and construction of check dams should be a common practice together with the use of low cost techniques for hill stabilization such as jute netting, gabion works, wire bolster cylinders and rip-rap drains.

The strategies as discussed above need to be applied in mitigating adverse impacts and strengthening hydropower projects within the hilly environment. But it is largely in the hands of the concerned authorities, local governments, technocrats, and local residents how they perceive and how they value these conservative measures against the direct benefits of the upcoming development of hydropower projects.

\section{Acknowledgements}

The authors wish to thank Ministry of Environment and Forest, New Delhi, Govt. of India for financial support and Director, Govind Ballabh Pant Institute of Himalayan Environment and Development Kosi-Katarmal, Almora, Uttarakhand for providing infrastructure support.

\section{References}

[1] Bartarya, S.K. and Sah, M.P. (1995) Landslide Induced River Bed Uplift in the Tal Valley of Garhwal Himalaya, India. Geomorphology, 12, 109-121. http://dx.doi.org/10.1016/0169-555X(94)00085-6

[2] Nath, S.K. (2004) Seismic Hazard Mapping and Microzonation in the Sikkim Himalaya through GIS Integration of Site Effects and Strong Ground Motion Attributes. Natural Hazards, 31, 319-342. http://dx.doi.org/10.1023/B:NHAZ.0000023355.18619.0c

[3] Khattak, G.A., Owen, L.A., Kamp, U. and Harp, E.L. (2010) Evolution of Earthquake-Triggered Landslides in the Kashmir Himalaya, northern Pakistan. Geomorphology, 115, 102-108. http://dx.doi.org/10.1016/j.geomorph.2009.09.035

[4] Korup, O., Densmore, A.L. and Schlunegger, F. (2010) The Role of Landslides in Mountain Range Evolution. Geomorphology, 120, 77-90. http://dx.doi.org/10.1016/j.geomorph.2009.09.017

[5] Kuenza, K., Dorji, Y. and Wangda, D. (2004) Landslides in Bhutan. Country Report, Department of Geology and Mines, Royal Government of Bhutan, Thimpu.

[6] Norbu, C., Baillie, I., Dema, K., Jamyang, Y., Dema, Y., Tshering, K., Tamang, H. and Turkelboom, F. (2003) Types of land degradation in Bhutan. Journal of Bhutan Studies, 8, 88-114.

[7] Sharma, S., Kuniyal, J.C., Agrawal, D.K. and Sharma, J.C. (2008) Role of Environmental Impact Assessment and Public Involvement in Sustainable Development of Hydropower Projects in the Mountains-A Case of the Beas Valley, Himachal Pradesh, India. Indian Journal of Power and River Valley Development, 58, 37-47.

[8] Kuniyal, J.C. and Sharma, R. (2008) Environmental Assessment of Hydropower Projects in the Himalayan Beas Valley of Himachal State, India. In: Singh, A.L. and Fazal, S., Eds., Rural Environmental Management, B.R. Publishing, Delhi, 227-268.

[9] Dharmadhikary, S. (2008) Mountains of Concrete. International Rivers Report, 1847, Berkeley, California.

[10] Chandrasekharan, M.E. (1995) Case Study of Reservoir Sedimentation in the Western Ghat Region of Kerala. In: Anonymous, Ed., Environmental Impact Assessment Studies (Case Studies), Central Board of Irrigation and Power, Pub. No. 248. New Delhi, 192-197.

[11] DDMGU (2012) Dehradun Geological Note on Baderkhila Landslip, Menagadnala Area at Gyansu Village in Uttarkashi. Department of Disaster Management Dehradun, Government of Uttarakhand. 
[12] GBPIHED (2011) Environmental and Social Impacts of Hydropower Plants in the Ganga River Basin. Final Technical Report, GB Pant Institute of Himalayan Environment and Development, Kosi-Katarmal, Almora.

[13] Sharma, M.C. and Owen, L.A. (1996) Quaternary Glacial History of the NW Garhwal, Central Himalayas, India. Quaternary Science Reviews, 1, 335-365. http://dx.doi.org/10.1016/0277-3791(95)00061-5

[14] Naithani, N.P. (1992) Study of Quaternary Sediments between Maneri and Gangnani Area, District Uttarkashi Garhwal Himalaya (U.P). Ph.D. Thesis, HNB Garhwal University Srinagar, Garhwal.

[15] Rana, N, Sati, S.P., Sundriyal, Y.P., Doval, M.M. and Juyal, N. (2007) Socio-Economic and Environmental Implication of the Hydroelectric Projects in Uttarakhand Himalaya, India. Journal of Mountain Sciences, 4, 344-353. http://dx.doi.org/10.1007/s11629-007-0344-5

[16] Agarwal, N.C. and Kumar, G. (1973) Geology of the Upper Bhagirathi and Yamuna Valleys, Uttarkashi District. Kumaun Himalaya, 3, 1-23.

[17] Metcalf, P.L. (1993) Landslide Investigation and Hazard Zonation in the Greymouth Urban Area. Unpublished MSc Thesis (Engineering Geology), University of Canterbury, Christchurch, 184.

[18] Owen, L.A., Sharma, M. C. and Bigwood, R. (1995) Mass Movement Hazard in the Garhwal Himalaya: The Effects of the 20 October 1991 Garhwal Earthquake and the July-August 1992 Monsoon Season. In: McGregor, D.F.M. and Thompson, D.A., Eds., Geomorphology and Land Management in a Changing Environment, Wiley, Chichester, 69-88.

[19] Owen, L.A., Sharma, M.C. and Bigwood, R. (1996) Landscape Modification and Geomorphological Consequences of the 20th October 1991 Earthquake and the July-August 1992 Monsoon in the Garhwal Himalaya. Zeitschriftfür Geomorphologie, 103, 359-372.

[20] Valdiya, K.S. (2001) Reactivation of Terrane-Defining Boundary Thrusts in Central Sector of the Himalaya: Implications. Current Science, 81, 1418-1431.

[21] Paul, S.K., Bartarya, S.K., Rautela, P. and Mahajan, A.K. (2000) Catastrophic Mass Movement of 1998 Monsoons at Malpa in Kali Valley, Kumaun Himalaya (India). Geomorphology, 35, 169-180. http://dx.doi.org/10.1016/S0169-555X(00)00032-5

[22] Barnard, P.L., Owen, A.L., Sharma, M.C. and Finkel, R.C. (2001) Natural and Human-Induced Land Sliding in the Garhwal Himalaya of Northern India. Geomorphology, 40, 21-35. http://dx.doi.org/10.1016/S0169-555X(01)00035-6

[23] Owen, L.A., Kamp, U., Khattak, A.G., Harp, E.L., Keefer, D.K. and Bauer, M.A. (2008) Landslides Triggered by the 8 October 2005 Kashmir Earthquake. Geomorphology, 94, 1-9. http://dx.doi.org/10.1016/j.geomorph.2007.04.007

[24] Korup, O., McSaveney, M.J. and Davies, T.R.H. (2004) Sediment Generation and Delivery from Large Historic Landslides in the Southern Alps, New Zealand. Geomorphology, 61, 189-207.

http://dx.doi.org/10.1016/j.geomorph.2004.01.001 
Scientific Research Publishing (SCIRP) is one of the largest Open Access journal publishers. It is currently publishing more than 200 open access, online, peer-reviewed journals covering a wide range of academic disciplines. SCIRP serves the worldwide academic communities and contributes to the progress and application of science with its publication.

Other selected journals from SCIRP are listed as below. Submit your manuscript to us via either submit@scirp.org or Online Submission Portal.
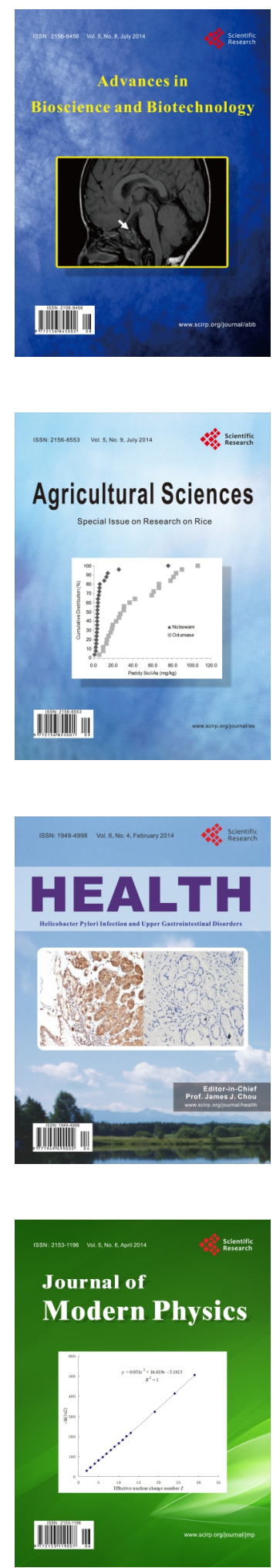
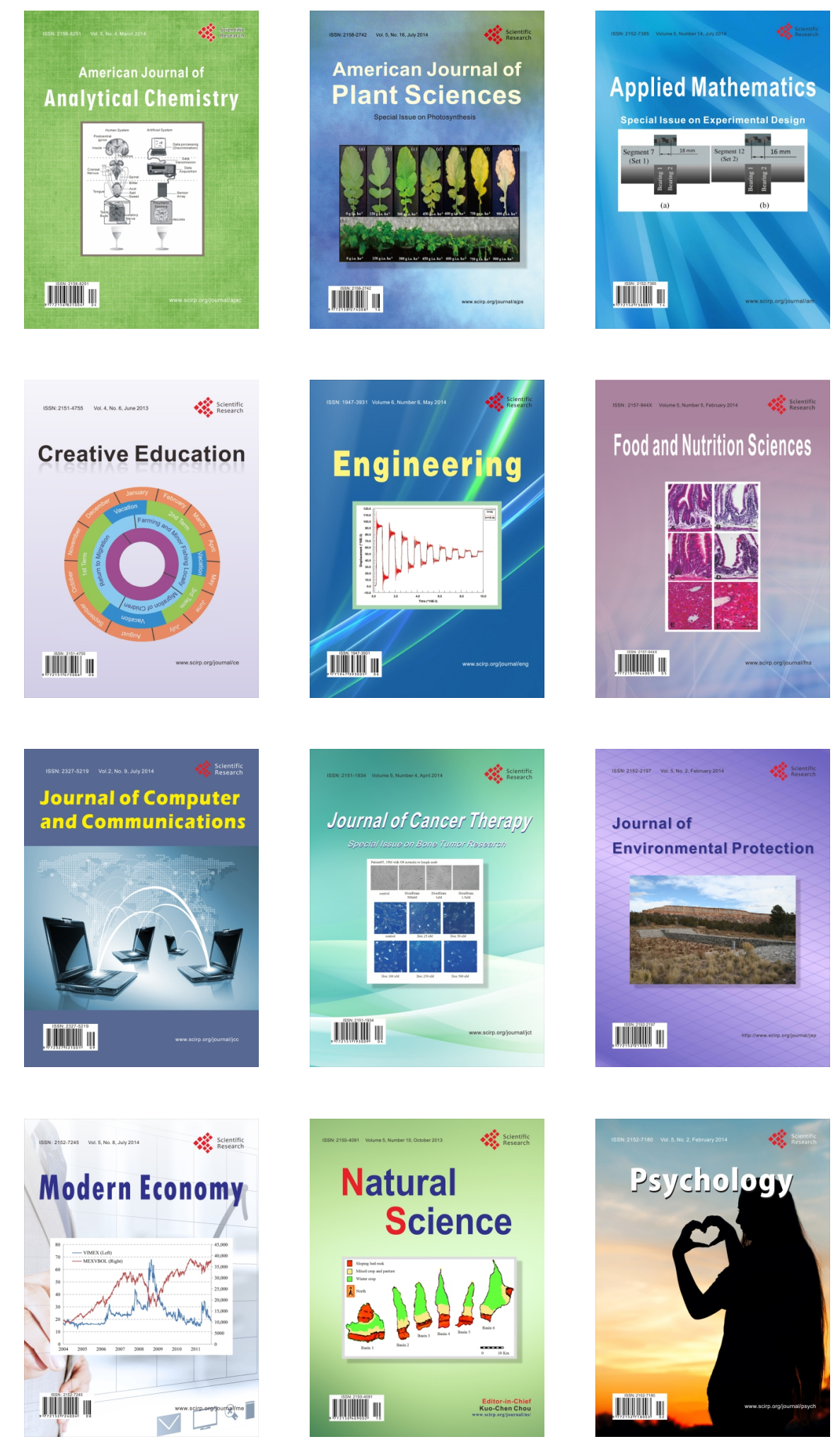